\title{
Mice subjected to aP2-Cre mediated ablation of microsomal triglyceride transfer protein are resistant to high fat diet induced obesity
}

\author{
Ahmed Bakillah ${ }^{1,2^{*}}$ and M. Mahmood Hussain ${ }^{1,2,3}$
}

\begin{abstract}
Background: Microsomal triglyceride transfer protein (MTP) is essential for the assembly of lipoproteins. MTP has been shown on the surface of lipid droplets of adipocytes; however its function in adipose tissue is not well defined. We hypothesized that MTP may play critical role in adipose lipid droplet formation and expansion.

Methods: Plasmids mediated overexpression and siRNA mediated knockdown of Mttp gene were performed in 3T3-L1 pre-adipocytes to evaluate the effects of MTP on cell differentiation and triglyceride accumulation. Adiposespecific knockdown of MTP was achieved in mice bybreeding MTP floxed $\left(M_{t t p} f^{f / f f}\right)$ mice with aP2-Cre recombinase transgenic mice. Adipose-specific MTP deficient $\left({\mathrm{A}-M t t p^{-/}}^{-}\right)$mice were fed $60 \%$ high-fat diet (HFD), and the effects of MTP knockdown on body weight, body fat composition, plasma and tissues lipid composition, glucose metabolism, lipogenesis and intestinal absorption was studied. Lipids were measured in total fasting plasma and size fractionated plasma using colorimetric assays. Gene expression was investigated by Real-Time quantitative PCR. All data was assessed using t-test, ANOVA.

Results: MTP expression increased during early differentiation in 3T3-L1 cells, and declined later. The increases in MTP expression preceded PPARY expression. MTP overexpression enhanced lipid droplets formation, and knockdown attenuated cellular lipid accumulation. These studies indicated that MTP positively affects adipogenesis. The ablation of the Mttp gene using aP2-Cre $\left(A-\mathrm{Mttp}^{-1}\right)$ in mice resulted in a lean phenotype when fed a HFD. These mice had reduced white adipose tissue compared with wild-type Mttpl/fll mice. The adipose tissue of A-Mttp ${ }^{-1}$ mice had increased number of smaller size adipocytes and less macrophage infiltration. Further, these mice were protected from HFD-induced fatty liver. The A-Mttp ${ }^{-1}$ mice had moderate increase in plasma triglyceride, but normal cholesterol, glucose and insulin levels. Gene expression analysis showed that the adipose tissue of the AMttp $^{-1-}$ mice had significantly lower mRNA levels of PPARY and its downstream targets.

Conclusion: These data suggest that MTP might modulate adipogenesis by influencing PPARY expression, and play a role in the accretion of lipids to form larger lipid droplets. Thus, agents that inactivate adipose MTP may be useful anti-obesity drugs.
\end{abstract}

Keywords: Adipose, Lipoproteins, Lipid droplets, Inflammation, Macrophages, Obesity, Microsomal triglyceride transfer protein, High fat diet

\footnotetext{
* Correspondence: Ahmed.Bakillah@downstate.edu

'Department of Cell Biology, SUNY Downstate Medical Center, 450 Clarkson

Avenue, Brooklyn, NY 11203, USA

${ }^{2}$ Department of Pediatrics, SUNY Downstate Medical Center, 450 Clarkson

Avenue, Brooklyn, NY 11203, USA

Full list of author information is available at the end of the article
} 


\section{Background}

The prevalence of obesity has steadily increased over the past three decades both in the United States and Worldwide, and it is associated with many diseases such as diabetes, dyslipidemia, cardiovascular disease and certain types of cancer [1-5]. Adipocytes are highly specialized cells that play an important role in the storage and utilization of fat as an energy source [6,7]. Their main function is to synthesize and store triglycerides when there are excess calories, and mobilize this fat to other organs when caloric intake is low. Tremendous efforts with a focus on energy metabolism and lipid homeostasis have been made to obtain information about different proteins that contribute to obesity and its related complications $[3,8,9]$.

Microsomal triglyceride transfer protein (MTP) assists in the assembly of triglyceride-rich lipoproteins in hepatic, intestinal, cardiac, embryonic yolk sac and glomeruli [10-13]. Besides these cells, MTP activity has been documented in adipocytes [14, 15] and macrophages [16] that do not synthesize lipoproteins. In adipose tissue, the amounts of MTP are 1 \% of the liver [14]. Similar low levels are also seen in macrophages suggesting that MTP expression is significantly lower in cells that do not assemble lipoproteins. In macrophages, MTP is involved in the biosynthesis of CD1 proteins that present glycolipid antigens to natural killer $\mathrm{T}$ (NKT) cells $[12,15,16]$. In apoB-producing cells, MTP physically interacts with apoB $[10,17,18]$, whereas in macrophages it interacts with CD1d [16]. In both cases, these proteins are loaded with lipids. In case of apoB, several hundred lipid molecules are added to generate lipoproteins. By contrast, one phospholipid molecule is added to the nascent CD1 proteins in the endoplasmic reticulum (ER) [12, 19, 20]. MTP could play a similar role in adipocytes. In fact, a recent study revealed that MTP might play a role in the presentation of endogenous lipid antigens to NKT cells in adipocytes [21].

In mice, two MTP isoforms have been identified [14-16]. These two isoforms differ by two amino acids at the $\mathrm{N}$-terminus and show no differences in their lipid transfer activity. MTP B is the major isoform in adipocytes $[14,15]$. In enterocytes, hepatocytes and macrophages, MTP A is mainly present in the ER $[16,22,23]$. By contrast, MTP B has been suggested to be mainly present in the Golgi of non-differentiated 3T3-L1 cells $[14,15]$. After differentiation, MTP was also seen on the surface of small lipid droplets [14]. Thus, there are significant differences about the subcellular localization of MTP in adipocytes as opposed to enterocytes and hepatocytes. The present study was designed to investigate potential role of MTP in adipocyte differentiation and lipid droplet formation. We hypothesized that adipose tissue MTP might participate in lipid droplet expansion by assisting in the fusion process of smaller lipid droplets and increasing their size. To test this, we used preadipocytes, 3T3-L1, and ablated the Mttp gene by breeding Mttp-floxed mice (Mttp $\left.p^{f l f l}\right)$ with aP2-Cre mice. Our studies demonstrate, for the first time, that MTP contributes to the biogenesis of larger lipid droplets in the adipose tissue.

\section{Methods \\ Cell culture and induction of differentiation of 3T3-L1 pre-adipocytes}

Extensive information has been obtained using cell culture models such as 3T3-L1 cells to study adipocyte differentiation $[8,24]$. Culture and differentiation of 3T3-L1 preadipocytes were performed as described in previous studies [25-27]. Briefly, 3T3-L1 cells, kindly provided by Dr. Brasaemle of the Rutgers University, were seeded at $2 \times 10^{5} /$ well of 6 -well plates and cultured in DMEM medium supplemented with $10 \% \mathrm{FBS}, 30 \mu \mathrm{M}$ biotin, $20 \mathrm{mM}$ of glutamine, $1 \mathrm{U} / \mathrm{ml}$ of penicillin/streptomycin. After confluence was reached, cell differentiation was induced by culturing in DMEM containing $1 \mu \mathrm{M}$ insulin, $1 \mu \mathrm{M}$ dexamethasone, and $0.5 \mathrm{mM}$ of 3-isobutyl1-methylxanthine (IBMX). After $48 \mathrm{~h}$, induction media was removed and replaced with DMEM containing $10 \%$ FBS, $1 \mu \mathrm{M}$ insulin, $20 \mathrm{mM}$ of glutamine and $1 \mathrm{U} / \mathrm{ml}$ of penicillin/streptomycin, and renewed every 2 days. Lipid droplets in differentiated adipocytes (day 6 to day 10) were identified under microscope and after Oil Red $\mathrm{O}$ staining. In subsequent experiments, MTP inhibitors (MTPi), kindly provided by Dr. David Gordon of BristolMyers Squibb, were added to the media after cell induction. Fresh doses of MTPi were renewed every 2 days (D0-D10).

\section{Animals and diets}

Transgenic mice expressing Cre recombinase under the control of rat $a P 2$ promoter (Tg (Fabp4-cre)1Rev or $a P 2$ Cre mice) were purchased from The Jackson Laboratory. In these mice, the expression of Cre was driven by the adipocyte protein 2 (aP2)-fatty acid binding protein 4 (FABP4) promoter. The C57/BL6J mice containing the floxed MTP allele Mttp $p^{f l f l(\text { exon5,6) }}$ [28] were bred with aP2-Cre mice to generate $a P 2-C r e^{+} / M t t p p^{f l / f(\text { exon5,6) }}$ mice, thereafter referred to as $A-M t t p^{-1-}$ mice. Due to the deletion of exons 5 and 6 these mice are deficient in both the A and B MTP isoforms that arise due to alternate splicing of the exon $1[15,16]$. Age and sex matched eight-weeks old female and male wild type (WT) $M t t p^{f l f l(\text { exon5,6) }}$ and $A-M t t p^{-1-}$ mice were fed a high fat diet (Rodent Diet with $60 \%$ kcal\% fat., catalog \#D12492, Research Diets, Inc., New Brunswick-NJ) for 15 and 24 weeks. All studies were approved by the Institutional Animal Care and 
Use Committee of State University of New York Downstate Medical Center.

\section{Measurements of plasma lipids and transaminases (ALT/AST)}

Total cholesterol and triglyceride (Thermo-Fisher Scientific), free cholesterol and free fatty acids (Wako Chemicals), and glycerol (Sigma) levels were measured in the plasma and tissues using commercial kits. Glycerol levels were subtracted from triglyceride levels. Plasma lipoproteins were separated by gel filtration (flow rate of $0.2 \mathrm{ml} / \mathrm{min}$ ) using a superpose-6-column, and $200-\mu \mathrm{l}$ fractions were collected. Fractions were used to measure cholesterol and triglycerides. To measure plasma transaminases, $2-5 \mu \mathrm{l}$ of plasma from $M t t p^{f l / f l}$ and $A-M t t p^{-/-}$mice were used for aspartate aminotransferase (AST) and alanine aminotransferase (ALT) assays using specific kits from BioTron Diagnostics (Hemet, CA) according to the manufacturer's guidelines.

\section{Determination of MTP activity}

Cells and small pieces (100 mg) of white adipose, liver and proximal intestine $(\sim 1 \mathrm{~cm})$ were homogenized in low salt buffer (1 mM Tris- $\mathrm{HCl}, \mathrm{pH} 7.6,1 \mathrm{mM}$ EGTA, and $1 \mathrm{mM} \mathrm{MgCl}_{2}$ ) and centrifuged, and supernatants were used for protein determination and the MTP assay $[29,30]$ using a commercial kit (Chylos, Inc.).

\section{Cell transfection with plasmid DNA or siRNA}

Plasmids pCMV6 (empty vector), pRcMTP expressing full length MTP, and MTP-FLAG have been previously described [30, 31]. SiRNA directed against mouse MTP (Sc-45276, MTP-siRNA) and nonspecific control siRNA (Sc-37007, Control) were obtained from Santa Cruz Biotechnology. Adipocytes were transfected in suspension as described by Kilroy et al. [32]. Briefly, 3T3-L1 cells were induced for 2 days and partially differentiated until day 4. At day 4, cells were trypsinized, resuspended in DMEM-high glucose containing $10 \%$ FBS and gently centrifuged. Cell pellets were resuspended in $200 \mu \mathrm{l}$ of OptiMEM (Gibco, Life Technologies) and incubated at $37{ }^{\circ} \mathrm{C}$ with equal volume of lipofectamine complexes (RNAiMax; Life Technologies) containing siRNA $(100 \mathrm{nM})$ or plasmid DNA $(1 \mu \mathrm{g} / \mathrm{ml})$. After $20 \mathrm{~min}$ incubation, the mixtures were plated in 6-well plates and incubated at $37{ }^{\circ} \mathrm{C}$ in $95 \% \mathrm{O}_{2}$ and $5 \% \mathrm{CO}_{2}$ atmosphere. After $24 \mathrm{~h}-72 \mathrm{~h}$ post-transfection, cells were harvested to measure protein, lipid, and MTP activity.

\section{Tissue histology and immunohistochemistry}

Samples of white adipose tissue and liver were fixed by overnight immersion in $4 \%$ paraformaldehyde in $0.1 \mathrm{M}$ phosphate buffer, dehydrated in $30 \%$ sucrose, embedded in $\mathrm{M} 1$ cryo-preservation media at $-20{ }^{\circ} \mathrm{C}$, and stored at $-80{ }^{\circ} \mathrm{C}$. To assess adipose tissue and liver morphology, sections $(5-7 \mu \mathrm{m})$ were placed on Tissue-Tack (Polysciences) slides and stained with hematoxylin and eosin (H \& E) [33, 34]. To assess fat cell number, white adipose tissue was incubated with $1 \mathrm{mg} / \mathrm{ml}$ of type I collagenase (Worthington Biochemical) for $1 \mathrm{~h}$ at $37{ }^{\circ} \mathrm{C}$ in Krebs buffer solution containing 1 \% BSA and $200 \mathrm{nM}$ adenosine and $50 \mu \mathrm{g} / \mathrm{ml}$ glucose and filtered through cheesecloth [35, 36]. Methylene blue was added to cell suspension and an aliquot was counted under microscope using a hemocytometer. To determine adipocyte size and number, stained samples were photographed using spot digital camera interfaced to an Olympus microscope and a Macintosh computer. Images of 100 adipocytes from each fat sample were converted into a binary format with public domain National Institutes of Health Image Program (Image J Basics, version 1.38). The data were averaged per section and then per animal. Other sections were used for immunostaining of adipose tissue macrophages using specific marker F4/80 [37-39]. Briefly, sections were incubated for $2 \mathrm{~h}$ at $25^{\circ} \mathrm{C}$ with antimouse F4/80 primary antibody (1:100 in $1 \%$ BSA/PBS; Abcam \#ab6640) followed by the application of HRPconjugated rabbit anti-goat IgG secondary antibody (Thermo Scientific, Pierce antibodies \#31433). Histochemical reactions were performed using the EnVision ${ }^{\mathrm{TM}}$ Dou- $^{-}$ blestain System (Dako) and counterstained with Hematoxylin. Sections were examined with a light microscopy, and digital images were taken to evaluate macrophage contents.

\section{Oil Red $\mathrm{O}$ staining and measurement of cellular lipid accumulation}

3T3-L1 cells were cultured and differentiated on sterile cover slips placed in 6-well plates. Differentiated cells were washed with PBS, fixed in $4 \%$ formaldehyde solution for $15 \mathrm{~min}$, washed with PBS and then stained for $1 \mathrm{~h}$ with Oil Red-O (Sigma-Aldrich Chemical) stain solution $0.5 \%$ in isopropanol:water (60:40) filtered through a $0.2 \mu \mathrm{m}$ filter. After several washes with water, pictures of samples were taken using a microscope [40]. Adipocyte differentiation was monitored by measuring cellular lipid accumulation using the same Oil Red-O staining method [40, 41]. Briefly, differentiated cells on 6-well plates were fixed with $10 \%$ ice-cold formalin in PBS for $2 \mathrm{~h}$ and stained by adding Oil Red-O working solution for $10 \mathrm{~min}$. Cells were thoroughly rinsed with water and the red dye retained by cells was eluted by adding isopropanol for $1 \mathrm{~h}$. Aliquots were transferred to wells of a 96-well plate and optical density was measured at $500 \mathrm{~nm}$ wavelength. Blank samples (with no cells) were treated similarly and background values were subtracted. In subsequent experiments when the Oil Red 
O stain is not used, cells were washed with PBS, lysed by polytron homogenizer in low salt buffer $(1 \mathrm{~mm}$ Tris- $\mathrm{HCl}$, pH 7.6, $1 \mathrm{~mm}$ EGTA, and $1 \mathrm{~mm} \mathrm{MgCl}_{2}$ ), and cellular lipids content were measured using commercial kits (Waco Chemicals; Thermo-Fisher Scientific).

\section{Glucose and insulin tolerance tests}

Whole body plasma glucose and insulin levels were measured after overnight fasting. For glucose tolerance test (GTT), mice were fasted overnight $(\sim 16 \mathrm{~h})$ with full access of water, and injected intraperitoneally with $2 \mathrm{mg}$ of glucose in saline solution/g of body weight. Blood glucose levels were measured at the indicated time points before and after glucose challenge. For insulin tolerance test (ITT), mice were fasted for $4 \mathrm{~h}$ prior to intraperitoneal injection of insulin (Novolin R, Novo Nordisk, Denmark; $0.75 \mathrm{U} / \mathrm{kg}$ body weight). Tail vein blood glucose was collected at the indicated times using a One-Touch basic glucometer (Bayer).

\section{Fatty acid oxidation and de novo lipogenesis}

For fatty acid oxidation measurements, $100 \mathrm{mg}$ of tissues (sliced in small pieces) were incubated with $\left[{ }^{14} \mathrm{C}\right]$-Oleic acid $(0.3 \mu \mathrm{Ci})$ for $2 \mathrm{~h}$ at $37^{\circ} \mathrm{C}$, and the radiolabeled $\mathrm{CO}_{2}$ was captured with filter paper soaked with phenylethylamine [42]. Radiolabel was quantified using a scintillation counter (Beckman LS 6000TA). Oxidation was presented per $\mathrm{mg}$ of protein. For de novo lipogenesis, $50 \mathrm{mg}$ of tissue slices were placed in $1 \mathrm{ml}$ Krebs-Ringer-Bicarbonate Hepes buffer containing $4 \%$ (wt/vol) fatty acid-free BSA fraction V (Sigma), $3 \mathrm{mM}$ glucose, $0.5 \mathrm{mM}$ acetate and $1 \mu \mathrm{Ci}\left[1-{ }^{14} \mathrm{C}\right]$-Acetate $(56 \mathrm{mCi} / \mathrm{mmol})$ at $37{ }^{\circ} \mathrm{C}$ for $2 \mathrm{~h}$ under $95 \% \mathrm{O}_{2}-5 \% \mathrm{CO}_{2}$. The reaction was terminated by the addition of $40 \mu \mathrm{l} 10 \mathrm{~N} \mathrm{H}_{2} \mathrm{SO}_{4}$, and radiolabel incorporation into lipids was determined [43].

\section{Postprandial triglyceridemic response and intestinal triglyceride secretion}

Mice were fasted for $4 \mathrm{~h}$ prior to the fat challenge. To study postprandial response, mice were administered with $200 \mu$ l olive oil (via oral gavage). Plasma triglyceride concentration was determined at baseline (time 0) and at $2 \mathrm{~h}$ and $4 \mathrm{~h}$. To assess intestinal triglyceride production, fasted mice $(4 \mathrm{~h})$ were injected with $\mathrm{P} 407$ (i.p.) to block lipase activity in the circulation. After $30 \mathrm{~min}$, mice were orally administered with $200 \mu \mathrm{l}$ olive oil, and plasma triglycerides were measured before and at $2 \mathrm{~h}$ and $4 \mathrm{~h}$ post fat load challenge.

\section{Gene expression and qPCR}

Total RNA from cells and tissues were isolated using TRIzol $^{\text {Tw }}$ (Invitrogen). The purity of RNA was assessed by the $A_{260} / A_{280}$ ratio. RNA preparations with $A_{260} / A_{280}$ ratios more than 1.7 were used for cDNA synthesis. The first strand cDNA was synthesized using Omniscript RT (Qiagen) kit. Each reaction of quantitative PCR was carried out in a volume of $20 \mu \mathrm{l}$, consisting of $5 \mu \mathrm{l}$ of cDNA sample (1:100 dilution of the first strand cDNA sample) and $15 \mu \mathrm{l}$ of PCR master mix solution containing $1 \times$ PCR buffer $\left(\mathrm{qPCR}^{\mathrm{m}}\right.$ core kit for SYBR Green I, Eurogentec). The PCR was carried out by incubating the reaction mixture first for $10 \mathrm{~min}$ at $95{ }^{\circ} \mathrm{C}$ followed by 40 cycles of $15 \mathrm{~s}$ incubation at $95{ }^{\circ} \mathrm{C}$ and $1 \mathrm{~min}$ at $60{ }^{\circ} \mathrm{C}$ in an ABI 7000 SDS PCR machine. Data were analyzed using $\Delta \Delta C_{T}$ method, according to the manufacturer's instructions using the following equation: $2^{[C T \text { house keeping }}$ gene - $C T$ target gene]. Final results are presented as arbitrary units that were normalized to $18 \mathrm{~S}$ mRNA.

\section{Statistical analyses}

Data are presented as mean \pm S.D. Statistical significance $(p<0.05)$ was determined using Student's $t$ test or oneway analysis of variance (GraphPad Prism 5).

\section{Results}

MTP activity changes during differentiation of 3T3-L1 cells do not correlate with adipogenesis

To understand how adipose tissue MTP might play a role in adipogenesis, we used 3T3-L1 cells that are routinely used to study adipocyte differentiation and adipogenesis. We studied changes in MTP activity during differentiation of these cells into adipocytes. Cells were treated with inducers of differentiation for 2 days and then cultured for 10 days. MTP activity increased in control cells (DMSO only) by 50-100 \% until day 4 , stayed high till day 6 , and then progressively declined until day 10 (Fig. 1a). We then measured changes in cellular lipids and droplet formation during this period. Intracellular cholesterol and fatty acids did not change significantly (data not shown). However, cellular triglyceride levels increased progressively during differentiation of control cells (Fig. 1b). Oil Red O staining also suggested higher amounts of lipids in differentiated cells (data not shown). These data suggest that MTP activity transiently increases during early differentiation and then declines later.

\section{Lipid transfer activity is not required for triglyceride accumulation during differentiation of 3 T3 L1 cells} Next, we sought to test the hypothesis that chemical inhibition of MTP lipid transfer activity in adipocytes would interfere with cell differentiation and/or adipogenesis. To test this, we treated 3T3-L1 cells with a potent pharmacological MTPi during differentiation. Supplementation of MTPi significantly reduced MTP activity during differentiation (Fig. 1a). MTPi did not affect intracellular triglyceride accumulation (Fig. 1b). No intracellular accumulation of cholesterol or free fatty acids was observed after MTPi treatment (Data not shown). These studies indicate that inhibition of MTP 




lipid transfer activity does not affect triglyceride accumulation during differentiation of 3T3-L1 cells.

\section{MTP expression is induced early during differentiation}

To understand reasons for increased MTP activity during early differentiation, we measured MTP mRNA levels (Fig. 1c). MTP mRNA levels increased by twofold, early during differentiation, and peaked at day four. In addition, MTPi had no effect on Mttp gene expression. The increases in MTP mRNA preceded increases in other adipocyte genes such as PPAR $\gamma$, Lipin and Fas (Fig. 1d). Thus, MTP appears to be an early response gene induced during preadipocyte differentiation.

\section{Knockdown and overexpression of MTP reduces and increases cellular triglyceride during differentiation of 3T3-L1 preadipocytes}

To address whether early induction of MTP is important for preadipocyte differentiation, we reduced and increased MTP expression using siRNA and expression plasmids, respectively. siMTP significantly reduced MTP expression
(Fig. 2a) and activity (Fig. 2b) by $82 \%$ to $80 \%$, respectively, without altering total cell protein (Fig. 2c). Reductions in MTP were associated with $47 \%$ decrease in lipid accumulation after Oil Red $\mathrm{O}$ staining (Fig. 2d). We also transfected differentiated 3T3-L1 cells with two different plasmids expressing human MTP cDNA resulting in significant increases in MTP activity (Fig. 2e) and cellular triglyceride after $48 \mathrm{~h}$ of transfection (Fig. 2f) with no effect on cellular protein levels (Fig. 2g). These studies indicated that changes in MTP levels directly correlate with changes in cellular triglyceride levels.

\section{AP2-Cre-mediated ablation of the Mttp gene in the adipose tissue results in lean mouse phenotype}

To study the role of MTP, we crossed $M t t p^{f l f l}$ mice with aP2-Cre mice and generated $A-M t t p^{-/-}$mice deficient in both the MTP isoforms. A-Mttp ${ }^{-1-}$ mice had $50 \%$ to $80 \%$ less MTP mRNA levels in the adipose tissue compared to controls (Fig. 3a). However, MTP mRNA levels were not different in the liver and intestine of WT and $A-M t t p^{-/-}$mice. Next, we measured MTP activity in 




different tissues (Fig. 3b). AP2 is known to be expressed in the brain and spleen (rich in macrophages), but MTP activity was not reduced in these tissues in $\mathrm{A}-\mathrm{Mttp}^{-/-}$ mice compared to WT (Fig. 3b). However, > 50 \% reduction in MTP activity was found in inguinal fat pads. Thus, $A-M t t P^{-/-}$mice have significant MTP deficiency in the adipose tissue.

On a chow diet, $M t t p^{f l / f l}$ and $A-M t t p^{-1-}$ mice gained similar weight (not shown). Next, we studied the development of obesity in Mttp $p^{f l f l}$ and $A-M t t p^{-/-}$mice. A$M t t p^{-/-}$mice appeared smaller in size and were leaner mainly due to significant absence of abdominal fat compared with control mice (Fig. 3c). Consistent with this, weights of inguinal and gonadal fat depots were $~ 50 \%$ less in $\mathrm{A}-\mathrm{Mttp}^{-1-}$ mice (Fig. 3d). Female and male $M t t p^{f l / f l}$ control mice gained significant weight when fed HFD (Fig. 3e-f), but $A-M t t p^{-1-}$ mice did not despite similar amounts of food consumption and body temperature (Fig. 3g-h). These studies indicated that $A$ $M t t p^{-/-}$mice are resistant to diet-induced obesity and accumulate less fat in their adipose tissue.

We then characterized the adipose tissue in these mice. A-Mttp ${ }^{-1-}$ mice had smaller size adipocytes (Fig. 4a). Adipocytes isolated from inguinal and gonadal fat of $A-\mathrm{Mttp}^{-/-}$mice had an average size of $2585 \mu \mathrm{m}^{2}$ as compared to $4500 \mu \mathrm{m}^{2}$ of the control mice (Fig. $4 \mathrm{~b}$ ). Further, the number of adipocytes obtained from $A-M t t p^{-/}$ inguinal fat was greater than the number obtained from WT mice (Fig. 4c). Thus, MTP deficiency increases the number of smaller adipocytes.

Increased macrophage infiltration in the adipose tissue is a common feature of obesity. Hence, we assessed whether adipose tissue macrophage infiltration was altered in $\mathrm{A}-\mathrm{Mttp}^{-/-}$mice. WT adipose tissue showed significant staining for macrophage specific-antigen F4/ 80 after 15 weeks and 24 weeks of HFD feeding (Fig. 4d). In contrast, the adipose tissue from the $A-M t t p^{-/-}$mice stained less for the macrophage antigen. These studies indicated that the adipose tissue of the $A-\mathrm{Mttp}^{-/-}$mice had less macrophage infiltration.

In short, these studies suggested that aP2-Cre mediated MTP ablation results in a leaner phenotype secondary to the presence of greater number of smaller size adipocytes with less number of macrophages in HFD fed mice.

\section{Ablation of MTP reduces PPARy expression and its downstream target genes}

To understand reasons for the lean phenotype, we measured mRNA levels of different genes that play a role in adipocyte differentiation (Fig. 5). As anticipated, MTP mRNA levels were significantly lower in the adipose tissue of $A$ $M t t p^{-/-}$mice. We also found significant reductions in PPARy, FABP4, FAS and lipins; other mRNA levels did not differ in two groups. This suggests that MTP deficiency might reduce PPAR $\gamma$ expression resulting in reduced differentiation and lower fat storage in the adipose tissue. 

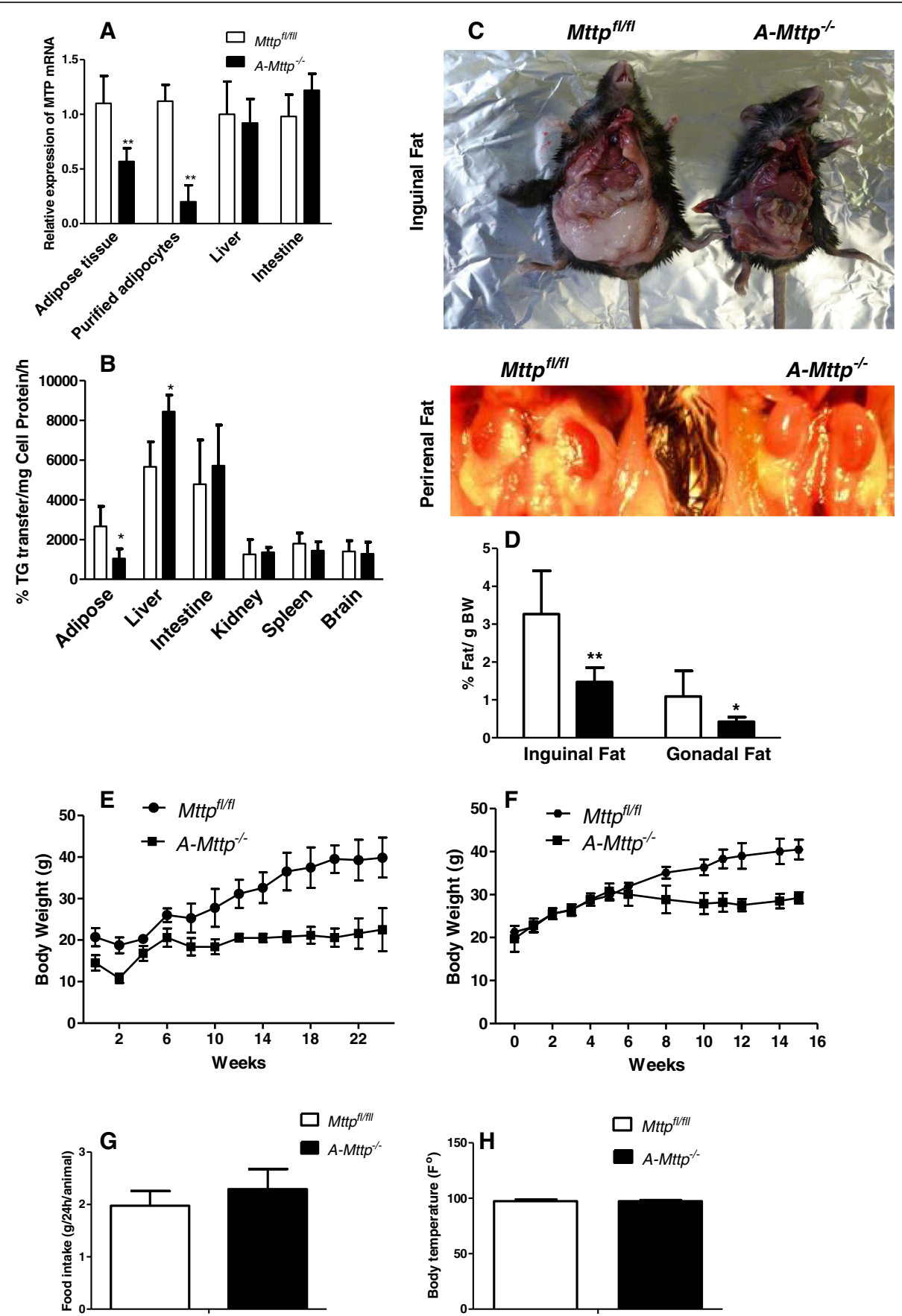

Fig. 3 aP2-Cre mediated MTP ablation reduces body weight and lipid accumulation in the adipose tissue. Mttp $p^{f / f l}$ and A-Mttp $p^{-/-}$mice were fed a HFD for 24 weeks. At the end of the experiment, control and A-Mttp ${ }^{-1-}$ mice were sacrificed and organs collected for MTP mRNA measurement (a) and MTP activity (b). Representative pictures of visceral fat pads and animal morphology are shown in panel (c). Percentages of fat in different adipose tissues by gram body weight are plotted in (d). Body weights were recorded every 2 weeks during the experiment using female (e) and male mice $(\mathbf{f})$. Data for food consumption and body temperature are represented in $(\mathbf{g} \& \mathbf{h})$. Values are mean of 5-7 mice \pm SD from each group. ${ }^{*}, p<0.05 ;{ }^{* *}, p<0.01$; and ${ }^{* * *}, p<0.001$

We then measured F4/80, a macrophage marker, and found to be significantly less in $A-M t t p^{-/-}$mice indicating less macrophage infiltration (Fig. 5). These studies indicate that $A-M t t p^{-/-}$mice were deficient in adipocyte differentiation and macrophage markers.
A-Mttp ${ }^{-/}$mice show normal blood glucose and insulin levels Next, we concentrated on glucose metabolism in $A$ $M t t p^{-/-}$mice. Fasting glucose and insulin levels did not differ significantly between WT and $A-\mathrm{Mttp}^{-/-}$mice (Fig. 6a-b). In addition, there were no significant 
A
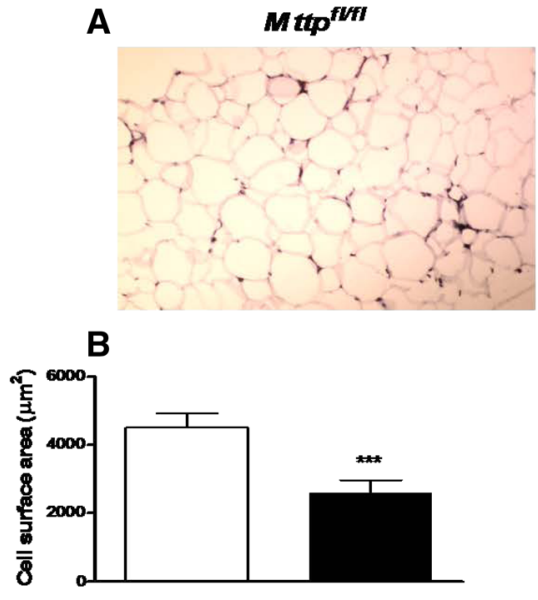

A-Mtpot-
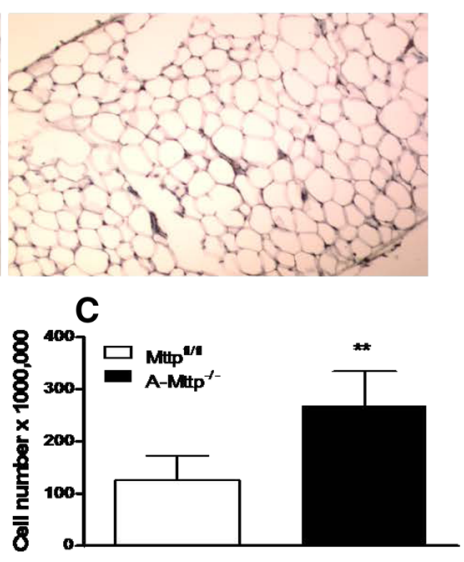

D


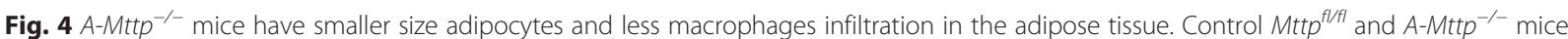
were fed 60 \% high fat diet for 15 and 24 weeks. At the end of experiment, adipose tissue was collected for H \& E staining (a), adipocyte size determination (b), and cell number quantification (c). Adipose tissue was isolated after collagenase treatment and counted under microscope. Immunohistochemical detection of cells expressing the macrophage-specific antigen F4/80 (arrows) was performed on paraffin section of adipose tissue in control Mttp ${ }^{f l f l}$ and $A-M_{t t p}^{-/-}$mice (d)

differences in the plasma glucose levels between WT and $A-M t t p^{-/-}$mice following glucose and insulin tolerance tests (Fig. 6c-d). Thus, $A-M t t p^{-/-}$mice showed no abnormality in glucose metabolism.

\section{A-Mttp ${ }^{-/-}$mice have higher levels of plasma triglyceride and normal levels of cholesterol}

HFD significantly increased fasting plasma triglyceride by week 18 and this increase continued until week 24 in $A-M t t p^{-/-}$mice (Fig. 7a). Fasting plasma cholesterol (Fig. 7b) and free fatty acids levels were similar in these two groups (not shown). Gel filtration analysis of fasting plasma pools from the two groups revealed an increase of triglyceride in the VLDL/LDL fraction of $A-\mathrm{Mttp}^{-/-}$mice (Fig. 7c) with no significant effect on cholesterol in both VLDL/LDL and HDL fractions (Fig. 7d). These studies suggest that
aP2-Cre mediated ablation of MTP increases plasma triglyceride-rich lipoproteins.

\section{A-Mttp ${ }^{-/-}$mice have increased adipose lipogenesis with no effect on $\beta$-oxidation}

We next studied the rate of de novo lipogenesis (DNL) and fatty acid oxidation by measuring incorporation of radiolabeled acetate and release of $\mathrm{CO}_{2}$, respectively. Adipose tissues from $A-M t t p^{-/-}$mice incorporated significantly higher amounts of acetate in newly synthesized fatty acids as compared to control $M t t p^{f l f l}$ mice (Fig. 8a). In contrast, hepatic DNL was significantly decreased in $A-M t t p^{-/-}$mice as compared to control mice. Fatty acid oxidation in adipose tissue and the liver was unchanged in $A-M t t p^{-/-}$mice as compared to control mice (Fig. 8b). These studies suggest that aP2-Cre mediated adipose 


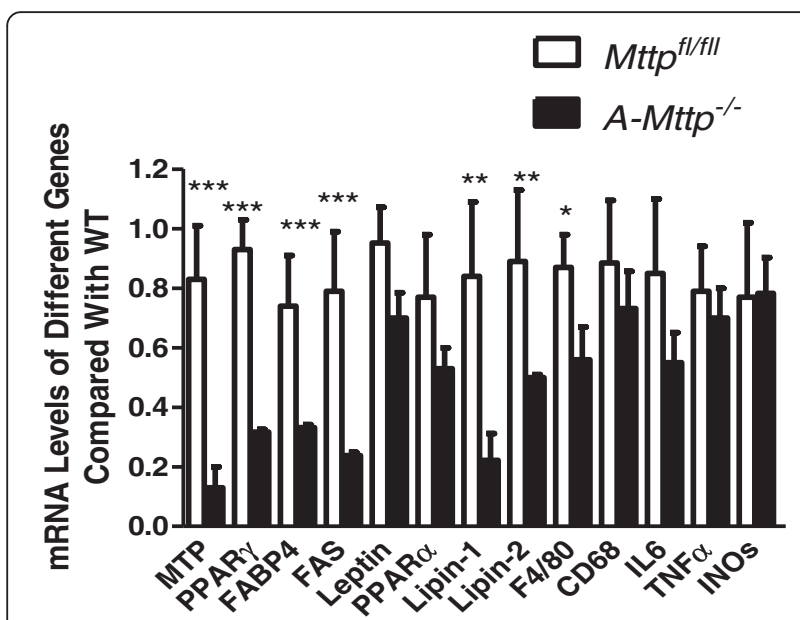

Fig. 5 aP2-Cre mediated MTP ablation reduces expression of genes involved in adipogenesis. Gene expression in the adipose tissue of $M t t p^{f / f l}$ and A-Mttp ${ }^{-/-}$mice was quantified by qPCR and levels were normalized to $18 \mathrm{~S}$ RNA. Mice were fed HFD for 24 weeks. After overnight fasting, animals were sacrificed, adipose tissues collected, and isolated inguinal fat adipocytes were used for total RNA extraction using Trizol reagent. CDNA was synthesized and levels of RNA were determined by qPCR. Data are represented as mean \pm SD $(N=4) .{ }^{*}, p<0.05 ;{ }^{*}, p<0.01$ and ${ }^{* *}, p<0.001$

MTP deficiency induces DNL in the adipose tissue but not in the liver.

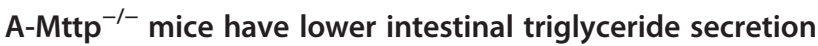
after an acute dietary fat challenge

To determine whether postprandrial triglyceridemic response was altered in lean $A-M t t p^{-/-}$mice compared to
$M t t p p^{f l f l}$ control mice, we measured plasma triglycerides concentration before and after $2 \mathrm{~h}$ and $4 \mathrm{~h}$ post olive oil bolus. At baseline, levels of plasma triglycerides were higher in lean $A-M t t p^{-1-}$ mice compared to $M t t p^{f l f l}$ control mice as expected, and remained high at $2 \mathrm{~h}$ then dropped at $4 \mathrm{~h}$ post olive oil gavage (Fig. 9a). Percent increase in plasma triglyceride in the two groups were similar at $2 \mathrm{~h}\left(A-\mathrm{Mttp}^{-/-}: 109.20 \% \pm 8.33 \%\right.$ vs. $M t t p^{f l / f l}$ : $128.75 \% \pm 14.25 \% ; p=0.1109)$ but decreased significantly after $4 \mathrm{~h}$ in $A-M t t p^{-/-}$mice $\left(A-M t t p^{-/-}: 51.76 \% \pm 8.45 \%\right.$ vs. $\left.M t t p^{f l / f l}: 98.16 \% \pm 18.71 \% ; p=0.0173\right)$. To determine whether these changes are secondary to lipoprotein production, we repeated the same experiment in mice injected with P407 to inhibit lipoprotein lipase. As expected, basal plasma triglycerides were higher in $A$ $M t t p^{-/-}$mice compared to $M t t p^{f l f l}$ control mice at baseline. $A-M t t p^{-/-}$mice had significantly lower amounts of triglycerides at $2 \mathrm{~h}$ and $4 \mathrm{~h}$ as compared to $M t t p p^{f l / f l}$ control mice (Fig. 9b). The percent increase in plasma circulating triglycerides was significantly lower at $2 \mathrm{~h}\left(A-M t t p^{-/}\right.$: $2084.79 \% \pm 139.75 \%$ vs. $M t t p^{f l f l}: 6326.82 \% \pm 705.39 \%$; $p<0.0001)$ and $4 \mathrm{~h}\left(A-M t t p^{-/-}: 2019.56 \% \pm 284.54 \%\right.$ vs. $\left.M t t p^{f l / f l}: 5388.21 \% \pm 940.34 \% ; p=0.0004\right)$ in $A$ $M t t p^{-1-}$ mice. We calculated the areas under the curves (AUC) and found that in the absence of P407, Mttp ${ }^{f l / f l}$ control mice had lower AUC value $\left(\mathrm{AUC}_{0-4}=276.09 \pm\right.$ 39.46) as compared to $A-M t t p^{-/-}$mice $\left(\mathrm{AUC}_{0-4}=\right.$ $464.13 \pm 49.50)$. In contrast, after blocking the lipase activity in the circulation, the AUC value of $M t t p^{f l f l}$ control mice was elevated $\left(\mathrm{AUC}_{0-4}=11587.17 \pm 1001.84\right)$ compared to $\mathrm{A}-\mathrm{Mttp}^{-/-}$mice $\left(\mathrm{AUC}_{0-4}=8397.79 \pm\right.$


Fig. $6 \mathrm{~A}-\mathrm{Mttp} \mathrm{p}^{-1-}$ mice show normal glucose metabolism. Plasma glucose (a) and insulin (b) levels were measured in overnight fasted HFD fed animals. Glucose $(\mathbf{c})$ and Insulin (d) tolerance tests were performed in Mttp ${ }^{\nexists / A}$ and A-Mttp ${ }^{-1-}$ mice fed a HFD for 15 weeks. For glucose tolerance test, mice were fasted overnight $(16 \mathrm{~h}$ ) before glucose challenge $(2 \mathrm{mg} / \mathrm{kg}$ body weight, i.p.). For insulin sensitivity test, mice were fasted for $4 \mathrm{~h}$ before ip insulin injection. Tail blood was collected before injection and after each $30 \mathrm{~min}$ up to $2 \mathrm{~h}$. Data are represented as mean $\pm \operatorname{SD}(N=4) .{ }^{*}, p<0.05$ 



Fig. 7 Increased plasma triglycerides in A-Mttp ${ }^{-1-}$ mice. Control Mttp ${ }^{f / f l}$ and A-Mttp ${ }^{-1-}$ mice were fed $60 \%$ HFD for 24 weeks. Blood samples were collected every 2 weeks and assessed for plasma triglycerides (a) and cholesterol (b) levels. Data are represented as mean $(N=5)$. Statistical differences between the two groups were obtained by one-way ANOVA analysis. ${ }^{* *}, p<0.05 ;{ }^{* *}, p<0.01$ and ${ }^{* * *}, p<0.001$. Fasting plasma pool was obtained from five mice in each group and applied to FPLC column for lipoprotein separation. Triglycerides (c) and cholesterol (d) were measured in each fraction

723.81). These studies indicate that $A-M t t p^{-/-}$mice absorb lower amounts of triglyceride suggesting that enhanced plasma triglycerides in lean $A-M t t p^{-/-}$mice under HFD is not due to alterations in triglycerides secretion by intestine.

\section{A-Mttp ${ }^{-/-}$mice are protected from HFD induced hepatic steatosis}

As expected, livers of WT mice fed a HFD were pale indicating fat accumulation (Fig. 10a). In contrast, livers of $A$ $M t t p^{-/-}$mice appeared normal. Consistent with this observation, livers from the WT mice weighed more than those from the $A-M t t p^{-/-}$mice (Fig. 10b). Hematoxylin and eosin staining showed more vacuoles in the livers of WT mice (Fig. 10c). Further, lipid analysis revealed that livers obtained from WT mice had higher amounts of triglyceride compared with $A-M t t p^{-/-}$mice (Fig. 10d). In contrast to the liver, accretions of triglyceride in the intestine were not different in these two groups. Hepatic cholesterol and free fatty acid contents were not different in these two groups of mice (Fig. 10e-f). Plasma transaminases are used to ascertain liver damage and function $(34,42)$. Interestingly, protection from hepatic steatosis in the $\mathrm{A}-\mathrm{Mttp}^{-/-}$mice was associated with significant decrease of plasma AST and ALT (Fig. 10g-h). These studies showed that $A-M t t p^{-1-}$ mice exhibit less hepatosteatosis compared to WT mice on a HFD.

\section{Discussion}

In this study, we asked whether MTP plays a role in adipocyte biology. Our studies showed that MTP is induced early during differentiation of 3T3-L1 cells before the induction of PPAR $\gamma$, a critical transcription factor for the differentiation of adipocytes. Further, we show for the first time that $A-M t t p^{-1-}$ mice are lean and resistant to diet-induced obesity when fed a high fat diet. The adipose tissue in these mice contained more number of smaller size adipocytes and had less macrophage infiltration. These studies suggest that MTP plays a role in determining size, number, and triglyceride content of adipocyte most likely by assisting in greater accretion of triglyceride and enhancing the size of adipocyte in high fat fed mice.

MTP expression changes during differentiation of 3T3-L1 preadipocytes into adipocytes. Undifferentiated 3T3-L1 preadipocytes had lipid transfer activity suggesting for the presence of pre-existing pools of MTP. Mttp gene was induced early during differentiation that preceded transcriptional regulation of key markers of differentiation such as PPARy consistent with other studies [21]. Mechanistic studies by other investigators 




have suggested that the induction of MTP in early differentiation might be due to the binding of $\mathrm{C} / \mathrm{EBP} \beta$ and $\mathrm{C} /$ EBP $\delta$ transcription factors to a specific region in the exon 1 of the MTTP gene [21]. Thus, MTP is an early response gene involved in adipocyte differentiation.

Our study shows that early expression of MTP during differentiation is critical for optimal lipid storage. Molecular approaches using siRNA-mediated knockdown of MTP and overexpression of MTP demonstrated that changes in MTP affect intracellular lipid storage and droplet formation (Fig. 2). Overexpression of MTP increases the accretion of triglyceride in differentiated 3T3-L1 cells, whereas knockdown reduces their accumulation. These data are consistent with those of Rakhshandehroo et al. [21] who reported that MTP depletion (stable shRNA knockdown of MTP) does not influence the differentiation of 3T3-L1 preadipocytes, as assessed by FABP4 expression. These data suggest that MTP plays a role in promoting adipogenesis and determines the amounts of lipids accreted by differentiated adipocytes. In contrast to these studies, MTPi did not interfere with triglyceride accumulation. Thus MTP protein, not its lipid transfer activity, might play

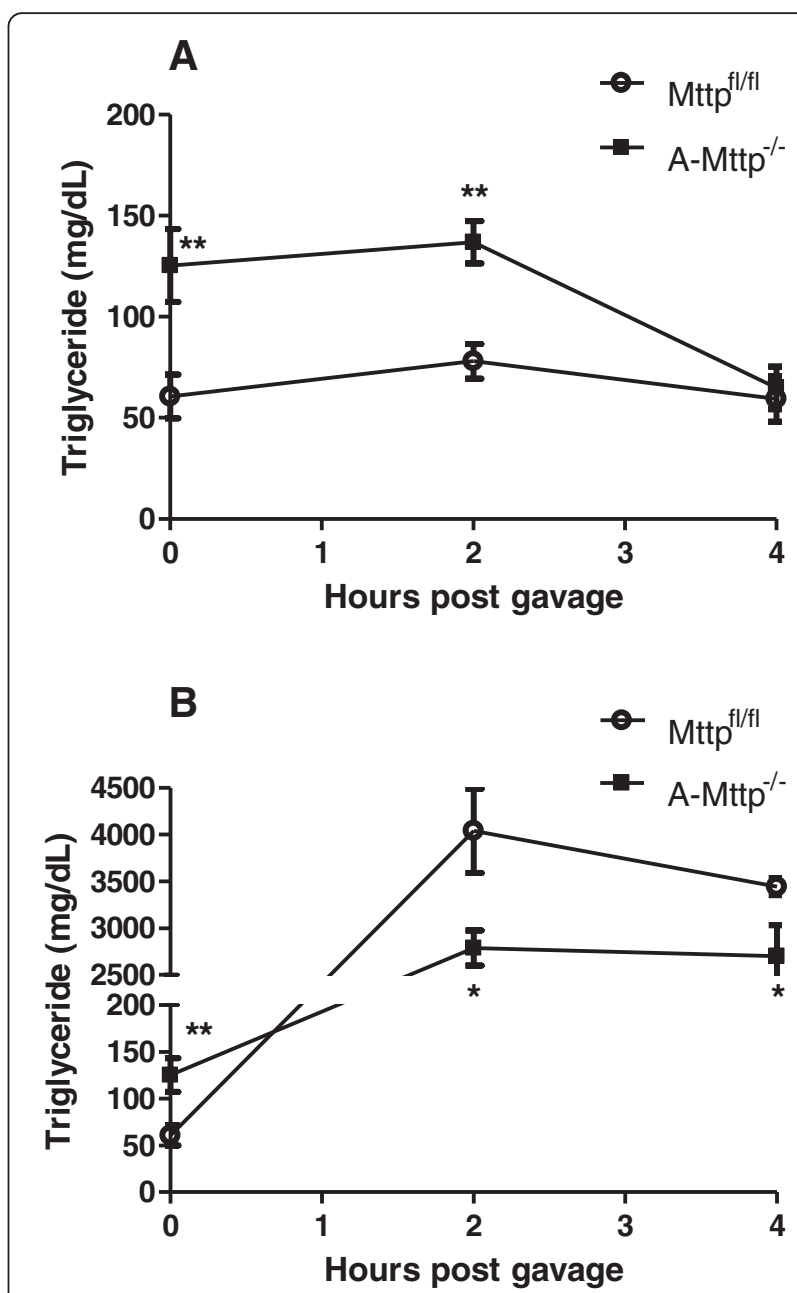

Fig. $9 \mathrm{~A}-M t t p^{-/-}$mice absorb fewer lipids after a fat tolerance test. Control Mttp ${ }^{f / A f}$ and $\mathrm{A}-\mathrm{Mttp}^{-/-}$mice were fed $60 \%$ HFD for 15 weeks. (a) Postprandial triglyceridemic response was measured in control $M t t p^{f / / l}$ and $\mathrm{A}-\mathrm{Mttp} \mathrm{p}^{-/-}$mice. Plasma triglyceride concentration was measured at baseline ( $4 \mathrm{~h}$ fasting) and at $2 \mathrm{~h}$ and $4 \mathrm{~h}$ following oral challenge of $200 \mu \mathrm{l}$ olive oil. Data are represented as mean \pm SD $(N=3)$. (b) After $4 \mathrm{~h}$ fasting, mice were injected with P407 in the intraperitoneal cavity to block lipase activity in the circulation. After $30 \mathrm{~min}$, mice were administered $200 \mu \mathrm{l}$ olive oil (oral gavage) and plasma triglycerides were measured before and at $2 \mathrm{~h}$ and $4 \mathrm{~h}$ post oil bolus. Data are represented as mean $\pm \mathrm{SD}(N=4) .{ }^{*}, p<0.05$ and $* *, p<0.01$

a role during adipocyte differentiation by assisting in the fusion of small droplets into larger droplets.

Surprisingly, treatment of cells with MTPi did not affect adipocyte differentiation and adipogenesis (Fig. 1). This is consistent with a recent finding demonstrating that the lipid transfer activity of MTP is neither critical for the mobilization of fatty acids from adipocytes nor for cell differentiation as assessed by the number of intracellular lipid droplets [44]. Our findings are also in agreement with another study dealing with the CD1dmediated lipid self-antigen presentation in adipocytes 

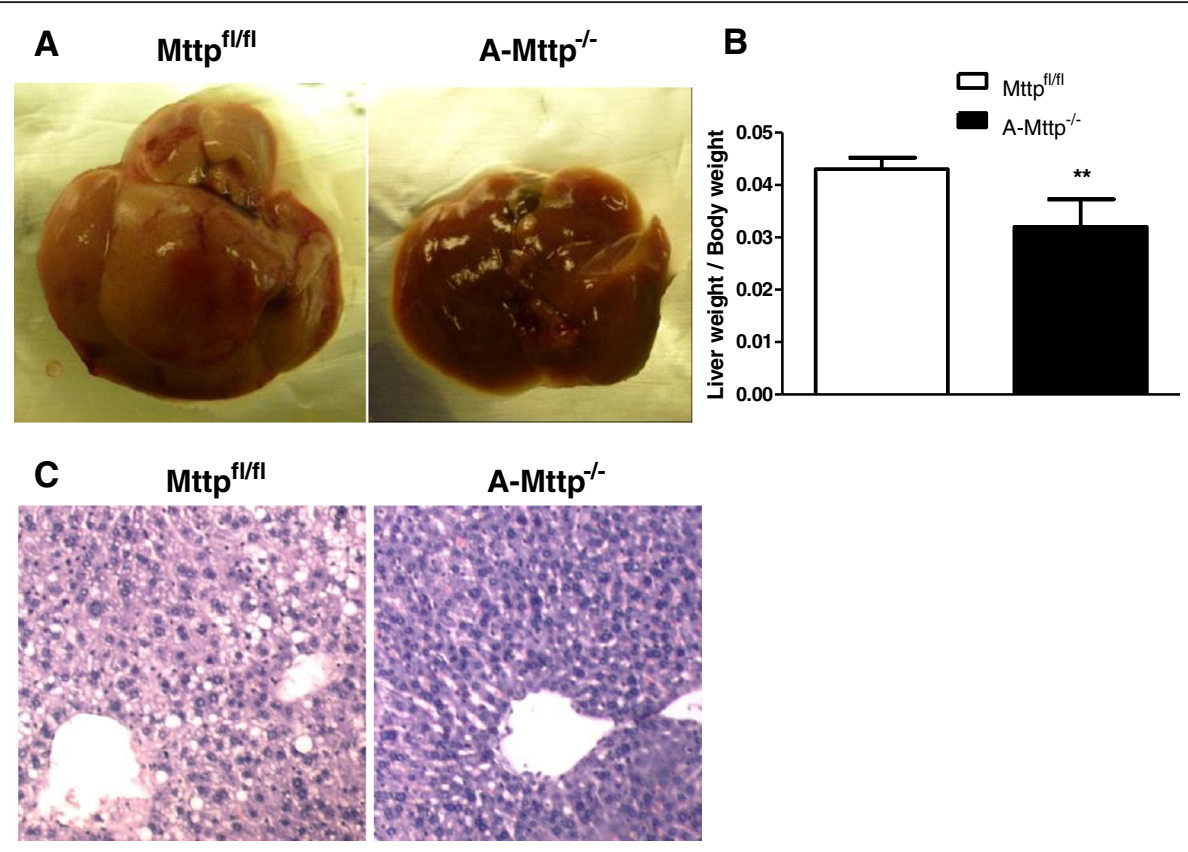

D


E



$\mathbf{F}$



ALT

$$
\square \operatorname{Mttp}^{\mathrm{f} / \mathrm{HII}}
$$

$\mathbf{H}$$$
\mathrm{Mttp}^{\mathrm{fl} / \mathrm{fll}}
$$

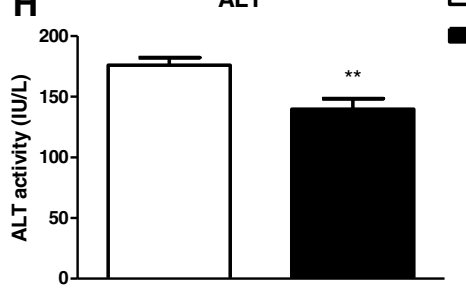

Fig. $10 \mathrm{~A}-\mathrm{Mttp}^{-/-}$mice are protected from HFD induced fatty liver. Control Mttp ${ }^{f / f l}$ and A-Mttp ${ }^{-/-}$mice were fed $60 \%$ HFD for 24 weeks. At the end of an experiment, overnight fasted animals were scarified and livers were collected (a), weighed (b) and fixed in paraffin and stored at $-80^{\circ} \mathrm{C}$ until use for $\mathrm{H} \& \mathrm{E}$ staining (c). Liver and intestine were homogenized and analyzed for triglyceride (d), cholesterol (e), and free fatty acid (f). Transaminase activities were measured on fasting plasma from five mice $(\mathbf{g} \& \mathbf{h}) .{ }^{* *}, p<0.05 ;{ }^{* *}, p<0.01$ and ${ }^{* * *}, p<0.001$; and data are mean $\pm S D(N=7)$

showing that treatment of adipocytes with BMS-212122 at high dose $(13 \mu \mathrm{M})$ for $24 \mathrm{~h}$ did not influence the differentiation potential of the preadipocytes [21]. Taken together, our results and observations from others suggest that MTP protein, but not its lipid transfer activity, may play a pivotal role in adipocyte lipid droplet formation and maturation. It is possible that MTP protein might be involved in the fusion of smaller lipid droplets to from larger droplets during adipocyte differentiation.

Understanding the precise function of MTP during adipocyte differentiation is critical in delineating its role in larger lipid droplet formation. MTP might participate in lipid accumulation via other mechanisms. Analysis of the expression pattern of relevant genes controlling adipocyte differentiation and adipogenesis identified that the induction of PPAR $\gamma$ was reduced in $A-M t t p^{-/-}$mice and the maximum expression of MTP occurs prior to the maximum expression of PPAR $\gamma$ in 3T3-L1 cells. PPARy is known to activate nearly all of the genes required for the formation of larger droplets, including FABP4 which is required for the transport of free fatty acids, and perilipin which is on the surface of mature lipid droplets. Thus, it is 
possible that reduced expression of PPAR $\gamma$ might be one mechanism contributing to reduced fat accumulation in MTP deficient adipocytes.

Another possibility is that MTP might interact with lipid droplet associated proteins, such as perilipin, and assist in droplet formation and/or stabilization of larger droplets. Immunohistochemical studies have shown that MTP surrounds small lipid droplets in 3T3-L1 adipocytes as well as in white and brown fat in mice $[14,15]$. MTP has been found to physically interact with apoB in lipoprotein producing cells $[10,18]$. Therefore, it is possible that MTP may interact with another protein(s) in adipocytes and act as a chaperone. For example, MTP could interact with one or more structural proteins on the surface of lipid droplets such as perilipin, adipophilin, TIP47, OXPAT/MLDP, and S3-12 [45-47], and assist in droplet fusion process by providing close access to triglycerides for smaller droplets, promoting lipid droplet growth and expansion. In fact, Love et al. demonstrated that MTP and perilipin- 2 were associated with the same isolated lipid droplets from adipocytes, but they concluded that these proteins do not interact with each other [44]. More studies are needed to explore possible physical interactions between MTP and lipid droplet-coating proteins.

Our finding of lean phenotype associated with reduced fat pad weight and lack of an increase of adipocyte size in HFD fed $A-M t t p^{-/-}$mice hints at a role of MTP in modulating adipocytes differentiation. Interestingly, reduction of fat mass in $A-M t t p^{-/-}$mice was accompanied with increased number of smaller adipocytes (Figs. 3 and 4). Thus, it is likely that basal cellular levels of triglycerides are unaffected by MTP. However, increased accumulation of fat during diet-induced obesity may require MTP. This is supported by the observation that $A-M t t p^{-1-}$ mice on chow do not show any difference in body weight compared to controls.

Metabolic defects that alter adipose tissue fat accumulation are frequently associated with changes in glucose homeostasis. Unexpectedly, plasma glucose and insulin levels in the fasted HFD-fed animals did not differ between the $A-M t t p^{-/-}$and WT mice. Further, despite marked reduction in body weight and adiposity, $A-M t t p^{-/-}$ mice did not exhibit any changes in whole-body glucose homeostasis and insulin sensitivity (Fig. 6). The reasons for no effect on glucose metabolism are not clear.

Using $1-{ }^{14} \mathrm{C}$ acetate as substrate, we observed that the adipose tissue and liver accounted for about $93 \%$ and $7 \%$ of DNL in WT mice. This in agreement with previous studies suggesting that adipose tissue DNL is a major site of lipogenesis in rodents [48-50]. In $A-M t t p^{-1-}$ mice, we found that DNL was significantly higher in the adipose tissue and was lower in the liver (Fig. 8). This is in good agreement with study showing significant elevation of adipose $\mathrm{DNL}$ in ob/ob mice in comparison with control mice
[51]. Numerous studies indicated that enhanced adipose DNL, in contrast to the liver DNL, may be beneficial for whole-body metabolism. For example, liver-specific deletion of SCAP, a protein required for the cleavage of SREBP1c to its active form, has been shown to reduce hepatic lipogenesis and enhance adipose DNL by four-fold resulting in improved glucose homeostasis [52]. In another study, ablation of adipocyte/macrophage lipid chaperones $a P 2$ (FABP4) and mal1 (FABP5) increased adipose DNL which protected mice from diet-induced obesity, fatty liver disease and insulin resistance [53]. The ob/ob mice that were rendered LPL deficient in adipose tissue also demonstrated increased DNL and diminished weight and fat mass [54]. Similar to these models, our finding suggest that increased DNL in adipocytes is associated with lean phenotype. The fact that DNL is upregulated while $\beta$-oxidation is decreased indicates for a possible higher rate of intracellular lipolysis and secretion of fatty acid from adipose tissue of lean $\mathrm{A}-\mathrm{Mttp^{-/- }}$ mice. More experiments are needed to illustrate potential impact of relevant lipases on the release of fatty acids and glycerol by adipose tissues.

Accumulation of adipose tissue macrophages has been well described in obese conditions in mice and humans [37, 55-57]. This process of macrophage infiltration is associated with adipocyte hypertrophy and metabolic dysfunction. In addition to the smaller size of adipocytes, we observed lesser macrophage infiltration in the adipose tissue of $A-M t t p^{-/-}$mice (Fig. 4). Thus, MTP deficiency in $A-M t t p^{-/-}$mice protects adipose tissue from HFD-induced macrophage infiltration.

Our studies also provide evidence that MTP deficiency in $A-M t t p^{-/}$mice modulates the expression of genes involved in adipocyte differentiation and lipid formation and storage. The expression of PPAR $\gamma$ and its downstream targets FAS, lipins and FABP4 were significantly reduced (55\%-75\%) in the adipose tissue of $A-M t t p^{-/}$ mice. PPAR $\gamma$ is essential for adipocyte viability and regulates a number of genes involved in lipid uptake and storage $[35,58,59]$. Down regulation of PPAR $\gamma$ could provide protection from HFD induced inflammation and obesity [60-65]. It remains unclear how ablation of MTP in $A-M t t p^{-/-}$mice impacts transcription of PPARY and protects mice from HFD induced inflammation and obesity.

Although $A-M t t p^{-/-}$mice consumed similar amounts of food, they did not accumulate fat in the adipose tissue and the liver compared with WT mice. Further, we did not find differences in rectal temperatures of these mice (Fig. 3). Thus, the physiologic reason for the leaner phenotype in these mice is not clear. It is possible that the $A-M t t p^{-/}$mice oxidize fat more efficiently and have higher metabolic rates than the WT mice. Future studies may identify the physiologic reasons for the leaner 
phenotype in $A-M t t p^{-/-}$mice when challenged with a high fat diet.

$A-\mathrm{Mtt}^{-/-}$mice have higher plasma triglyceride (Fig. 7). These mice showed modest increase ( 28 \%) in hepatic MTP activity but mRNA levels did not change (Fig. 3). Thus, changes in hepatic MTP do not explain increases in plasma triglyceride in $A-M t t p^{-/}$mice. Further, intestinal lipoprotein assembly and secretion was reduced, not increased. Therefore, increased lipoprotein production is unlikely to be responsible for higher plasma triglyceride in these mice. In addition, postprandial secretion of triglycerides in response to acute fat challenge was significantly decreased in $A-M t t p^{-/-}$mice after a $4 \mathrm{~h}$ oral fat tolerance test. These mice absorbed lesser amounts of fat than control. Further, we observed reduced lipid absorption in lipase inhibited $A-M t t p^{-/-}$ mice (Fig. 9). It is plausible that triglyceride elevations might be secondary to reduced amounts of lipoprotein lipase. This is based on several studies that show that adipocyte lipoprotein lipase is reduced in high fat fed animals. In fact, in recent study [66], mice lacking prostaglandin E receptor subtype 4 (EP4) manifested disrupted lipid metabolism associated with a $69 \%$ reduction in weight gain and fat mass following HFD feeding. Plasma triglycerides in these mice were elevated by $245 \%$. Authors found that these mice had reduced lipoprotein lipase activity, the key enzyme responsible for trafficking of plasma triglycerides into peripheral tissues.

The data obtained with 3T3-L1 cells and high fat fed $A-M t t p^{-/-}$mice appear to provide different results. If we assume that $3 \mathrm{~T} 3$ cell culture studies are comparable to chow fed mice, then results in cells and mice are the same. Both cells and mice do not show any significant difference in fat accumulation during MTP deficiency. We only saw the effect of MTP deficiency when mice were fed a high fat diet. We did not do similar fat challenge studies in cells. Thus, adipose MTP might be more critical when cells are exposed to high lipids.

We are aware that adipocytes express two MTP isoforms, A and B. Dr. Swift's laboratory was the first to establish the presence of MTP in adipose tissue as well as in the pre-adipocyte cell line, 3T3-L1 [14]. The group has previously generated anti-MTP antibodies from a 19-amino acid peptide representing residues 843 through 861 in the MTP protein. In a recent report [44], they were able to monitor mRNA and protein levels of both the MTP isoforms in adipocytes. They showed that adipocytes predominantly ( $>95 \%$ ) express MTP B isoform and demonstrated that MTP protein expression increased linearly over the 8-day period of differentiation, but mRNA levels for MTP-A and MTP$B$ did not change significantly. In another study, MTPB mRNA levels increased significantly within the first two days of differentiation and decreased slightly afterwards [21]. This later report is in good agreement with our observation for the decline of MTP expression at late stages of differentiation. Therefore, it is likely that MTP-B is the major isoform in adipocyte. Further, it should be pointed that no functional differences between these two isoforms have been reported. Therefore, expressions of these two different isoforms as determined by mRNA or protein levels do not appear to have any functional consequences.

In this study, we used $a P 2-C r e$ to ablate the Mttp gene. In these mice, MTP expression was greatly diminished in isolated adipocytes $(>80 \%)$ and decreased by $\sim 50 \%$ in adipose tissue which also includes nonadipocyte cell types. We are aware that aP2-Cre is expressed in adipocytes and macrophage. Therefore, the observed effects might be due to the deletion of MTP in both the adipose tissue and macrophages. In our study, we found significant reductions in the adipose tissue MTP but not in the spleen, a tissue rich in macrophages. Thus, it is likely that the observed effects are due to MTP deficiency in the adipose tissues. It is unlikely that reduction in T-cell mediated immune response due to possible deletion of MTP in macrophages could account for the lean phenotype and metabolic changes observed in $A-M t t p^{-/-}$mice for the following reasons: (1) iNKT cell population and CD1d expression is reduced in the adipose tissue of obese mice and humans compared to those of lean subjects [67]; (2) iNKT cell-specific J $\alpha 18$ knockout mice are obese and exhibit increased adipose tissue inflammation at the early stage of obesity [68]; (3) CD1d-deficient mice fed a high-fat diet show insulin resistance and hepatic steatosis [69-71]. Future studies may dissect the role of MTP in the adipose tissue and macrophages using cell-specific deletion of the gene.

\section{Conclusion}

In short, our study provides the first evidence of the role played by MTP in adipocyte differentiation and fat storage in mice. Ablation of the Mttp gene using aP2Cre has no effect on glucose homeostasis but it prevents HFD induced hepatosteatosis. We present evidence that MTP protein plays a role in the accumulation of larger lipid droplets in the adipose tissue. We speculate that MTP may (1) activate expression of PPAR $\gamma$ and amplify expression of genes critical for adipocyte maturation and lipid storage, (2) interact with lipid droplet associated proteins, and/or (3) assist in the fusion of smaller lipid droplets. Future investigation of how MTP ablation could repress PPAR $\gamma$ transcriptional activity should provide additional insights into the role of MTP in adipocyte maturation and physiology. It is 


\section{possible that down regulation of adipose MTP might avoid complications associated with obesity.}

\section{Abbreviations}

ALT: alanine aminotransferase; AP2: adipocyte protein 2; ApoB: apolipoprotein B; AST: aspartate aminotransferase; CD1: cluster of differentiation 1; DNL: de novo lipogenesis; ER: endoplasmic reticulum; FABP4: fatty acid binding protein 4; FAS: fatty acid synthase; FBS: fetal bovine serum; GTT: glucose tolerance test; HFD: high-fat diet; IBMX: 3-isobutyl-1-methylxanthine; ITT: insulin tolerance test; MTP: Microsomal triglyceride transfer protein; NKT: natural killer T cells; PPARY: peroxisome proliferator-activated receptor gamma; TG: triglycerides.

\section{Competing interests}

The authors declare that they have no competing interests.

\section{Authors' contributions}

$\mathrm{AB}$ and $\mathrm{MMH}$ conceived and designed the experiments. $\mathrm{AB}$ conducted the experiments and wrote the paper. $A B$ analyzed the data and performed statistical analysis. MMH involved in critical editing of manuscript. All authors read and approved the final manuscript.

\section{Acknowledgement}

This work was supported in part by US National Institutes of Health grants HL-95924 and VA Merit Award (BX001728) to MMH. AB was recipient of a $\mathrm{NIH/NHLBI}$ Diversity Supplement Award (HL09524-03S1). Part of this work was presented at the Arteriosclerosis Thrombosis and Vascular Biology/ Peripheral Vascular Disease 2015 Scientific sessions meeting, May 7-9; San Francisco-California, USA.

\section{Author details}

'Department of Cell Biology, SUNY Downstate Medical Center, 450 Clarkson Avenue, Brooklyn, NY 11203, USA. 'Department of Pediatrics, SUNY Downstate Medical Center, 450 Clarkson Avenue, Brooklyn, NY 11203, USA. ${ }^{3}$ VA New York Harbor Healthcare System, Brooklyn, NY 11209, USA.

\section{Received: 28 October 2015 Accepted: 3 January 2016}

\section{Published online: 08 January 2016}

\section{References}

1. Karpe F, Dickmann JR, Frayn KN. Fatty acids, obesity, and insulin resistance: time for a reevaluation. Diabetes. 2011:60:2441-9.

2. Greenberg AS, Coleman RA, Kraemer FB, McManaman JL, Obin MS, Puri V, et al. The role of lipid droplets in metabolic disease in rodents and humans. J Clin Invest. 2011;121:2102-10.

3. Krahmer N, Farese Jr RV, Walther TC. Balancing the fat: lipid droplets and human disease. EMBO Mol Med. 2013;5:905-15.

4. Wagner M, Samdal Steinskog ES, Wiig H. Adipose tissue macrophages: the inflammatory link between obesity and cancer? Expert Opin Ther Targets. 2015:19:527-38

5. Lavie CJ, McAuley PA, Church TS, Milani RV, Blair SN. Obesity and cardiovascular diseases: implications regarding fitness, fatness, and severity in the obesity paradox. J Am Coll Cardiol. 2014;63:1345-54.

6. Gesta S, Tseng YH, Kahn CR. Developmental origin of fat: tracking obesity to its source. Cell. 2007:131:242-56.

7. Frayn KN, Tan GD, Karpe F. Adipose tissue: a key target for diabetes pathophysiology and treatment? Horm Metab Res. 2007;39:739-42.

8. Gregoire FM, Smas CM, Sul HS. Understanding adipocyte differentiation. Physiol Rev. 1998:78:783-809.

9. Walther TC, Farese Jr RV. Lipid droplets and cellular lipid metabolism. Annu Rev Biochem. 2012:81:687-714.

10. Hussain MM, Bakillah A. New approaches to target microsomal triglyceride transfer protein. Curr Opin Lipidol. 2008:19:572-8.

11. Bartels ED, Nielsen JM, Hellgren LI, Ploug T, Nielsen LB. Cardiac expression of microsomal triglyceride transfer protein is increased in obesity and serves to attenuate cardiac triglyceride accumulation. PLoS One. 2009:4:e5300.

12. Hussain MM, Rava P, Walsh M, Rana M, Iqbal J. Multiple functions of microsomal triglyceride transfer protein. Nutr Metab (Lond). 2012;9:14

13. Eresheim C, Plieschnig J, Ivessa NE, Schneider WJ, Hermann M. Expression of microsomal triglyceride transfer protein in lipoprotein-synthesizing tissues of the developing chicken embryo. Biochimie. 2014;101:67-74.
14. Swift LL, Kakkad B, Boone C, Jovanovska A, Jerome WG, Mohler PJ, et al. Microsomal triglyceride transfer protein expression in adipocytes: a new component in fat metabolism. FEBS Lett. 2005;579:3183-9.

15. Mohler PJ, Zhu MY, Blade AM, Ham AJ, Shelness GS, Swift LL. Identification of a novel isoform of microsomal triglyceride transfer protein. J Biol Chem. 2007;282:26981-8.

16. Dougan SK, Salas A, Rava P, Agyemang A, Kaser A, Morrison J, et al. Microsomal triglyceride transfer protein lipidation and control of CD1d on antigen-presenting cells. J Exp Med. 2005;202:529-39.

17. Bradbury P, Mann CJ, Kochl S, Anderson TA, Chester SA, Hancock JM, et al. A common binding site on the microsomal triglyceride transfer protein for apolipoprotein B and protein disulfide isomerase. J Biol Chem. 1999:274:3159-64.

18. Bakillah A, Nayak N, Saxena U, Medford RM, Hussain MM. Decreased secretion of ApoB follows inhibition of ApoB-MTP binding by a novel antagonist. Biochemistry. 2000;39:4892-9.

19. Sagiv Y, Bai L, Wei DG, Agami R, Savage PB, Teyton $L$, et al. A distal effect of microsomal triglyceride transfer protein deficiency on the lysosomal recycling of CD1d. J Exp Med. 2007:204:921-8.

20. Kaser A, Hava DL, Dougan SK, Chen Z, Zeissig S, Brenner MB, et al. Microsomal triglyceride transfer protein regulates endogenous and exogenous antigen presentation by group 1 CD1 molecules. Eur J Immunol. 2008;38:2351-9.

21. Rakhshandehroo M, Gijzel SM, Siersbaek R, Broekema MF, de Haar C, Schipper $H S$, et al. CD1d-mediated presentation of endogenous lipid antigens by adipocytes requires microsomal triglyceride transfer protein. J Biol Chem 2014;289:22128-39.

22. Dougan SK, Rava P, Hussain MM, Blumberg RS. MTP regulated by an alternate promoter is essential for NKT cell development. J Exp Med. 2007;204:533-45.

23. Iabal J, Hussain MM. Intestinal lipid absorption. Am J Physiol Endocrinol Metab. 2009;296:e1 183-94

24. Prokesch A, Hackl H, Hakim-Weber R, Bornstein SR, Trajanoski Z. Novel insights into adipogenesis from omics data. Curr Med Chem. 2009;16:2952-64.

25. Brasaemle DL, Dolios G, Shapiro L, Wang R. Proteomic analysis of proteins associated with lipid droplets of basal and lipolytically stimulated 3T3-L1 adipocytes. J Biol Chem. 2004:279:46835-42.

26. Scott MA, Nguyen VT, Levi B, James AW. Current methods of adipogenic differentiation of mesenchymal stem cells. Stem Cells Dev. 2011;20:1793-804.

27. Poulos SP, Dodson MV, Hausman GJ. Cell line models for differentiation: preadipocytes and adipocytes. Exp Biol Med (Maywood). 2010;235:1185-93.

28. Chang BH, Liao W, Li L, Nakamuta M, Mack D, Chan L. Liver-specific inactivation of the abetalipoproteinemia gene completely abrogates very low density lipoprotein/low density lipoprotein production in a viable conditional knockout mouse. J Biol Chem. 1999:274:6051-5.

29. Athar H, Iqbal J, Jiang XC, Hussain MM. A simple, rapid, and sensitive fluorescence assay for microsomal triglyceride transfer protein. J Lipid Res. 2004;45:764-72

30. Rava P, Ojakian GK, Shelness GS, Hussain MM. Phospholipid transfer activity of microsomal triacylglycerol transfer protein is sufficient for the assembly and secretion of apolipoprotein B lipoproteins. J Biol Chem. 2006;281:11019-27.

31. Khatun I, Walsh MT, Hussain MM. Loss of both phospholipid and triglyceride transfer activities of microsomal triglyceride transfer protein in abetalipoproteinemia. J Lipid Res. 2013:54:1541-9.

32. Kilroy G, Burk DH, Floyd ZE. High efficiency lipid-based siRNA transfection of adipocytes in suspension. PLoS One. 2009:4:e6940.

33. Galarraga M, Campion J, Munoz-Barrutia A, Boque N, Moreno $H_{\text {, }}$ Martinez JA, et al. Adiposoft: automated software for the analysis of white adipose tissue cellularity in histological sections. J Lipid Res. 2012;53:2791-6

34. Josekutty J, Iqbal J, Iwawaki T, Kohno K, Hussain MM. Microsomal triglyceride transfer protein inhibition induces endoplasmic reticulum stress and increases gene transcription via Ire1alpha/cJun to enhance plasma ALT/AST. J Biol Chem. 2013;288:14372-83.

35. Sugii S, Olson P, Sears DD, Saberi M, Atkins AR, Barish GD, et al. PPARgamma activation in adipocytes is sufficient for systemic insulin sensitization. Proc Natl Acad Sci U S A. 2009:106:22504-9.

36. Majka SM, Miller HL, Helm KM, Acosta AS, Childs CR, Kong R, et al. Analysis and isolation of adipocytes by flow cytometry. Methods Enzymol. 2014:537:281-96. 
37. Weisberg SP, McCann D, Desai M, Rosenbaum M, Leibel RL, Ferrante Jr AW. Obesity is associated with macrophage accumulation in adipose tissue. J Clin Invest. 2003;112:1796-808.

38. Zhang L, Sugiyama T, Murabayashi N, Umekawa T, Ma N, Kamimoto Y, et al. The inflammatory changes of adipose tissue in late pregnant mice. J Mol Endocrinol. 2011:47:157-65.

39. Cao Q, Wang Y, Wang XM, Lu J, Lee W, Ye Q, et al. Renal F4/80+ CD11C + mononuclear phagocytes display phenotypic and functional characteristics of macrophages in health and in adriamycin nephropathy. J Am Soc Nephrol. 2015;26:349-63.

40. Mehlem A, Hagberg CE, Muhl L, Eriksson U, Falkevall A. Imaging of neutral lipids by oil red $\mathrm{O}$ for analyzing the metabolic status in health and disease. Nat Protoc. 2013;8:1149-54

41. Sung HY, Kang SW, Kim JL, Li J, Lee ES, Gong JH, et al. Oleanolic acid reduces markers of differentiation in 3T3-L1 adipocytes. Nutr Res. 2010;30:831-9.

42. Ibrahimi A, Bonen A, Blinn WD, Hajri T, Li X, Zhong K, et al. Muscle-specific overexpression of FAT/CD36 enhances fatty acid oxidation by contracting muscle, reduces plasma triglycerides and fatty acids, and increases plasma glucose and insulin. J Biol Chem. 1999;274:26761-6.

43. Harada N, Oda Z, Hara Y, Fujinami K, Okawa M, Ohbuchi K, et al. Hepatic de novo lipogenesis is present in liver-specific ACC1-deficient mice. Mol Cell Biol. 2007;27:1881-8.

44. Love JD, Suzuki T, Robinson DB, Harris CM, Johnson JE, Mohler PJ, et al. Microsomal Triglyceride Transfer Protein (MTP) Associates with Cytosolic Lipid Droplets in 3T3-L1 Adipocytes. PLoS One. 2015;10:e0135598.

45. Wolins NE, Rubin B, Brasaemle DL. TIP47 associates with lipid droplets. J Biol Chem. 2001;276:5101-8.

46. Brasaemle DL, Subramanian V, Garcia A, Marcinkiewicz A, Rothenberg A. Perilipin A and the control of triacylglycerol metabolism. Mol Cell Biochem. 2009;326:15-21.

47. Konige M, Wang $H$, Sztalryd C. Role of adipose specific lipid droplet proteins in maintaining whole body energy homeostasis. Biochim Biophys Acta. 2014;1842:393-401.

48. Jansen GR, Zanetti ME, Hutchison CF. Studies in lipogenesis in vivo: Fatty acid and cholesterol synthesis during starvation and re-feeding. Biochem J. 1966;101:811-8.

49. O'Hea EK, Leveille GA. Influence of fasting and refeeding on lipogenesis and enzymatic activity of pig adipose tissue. J Nutr. 1969;99:345-52.

50. Hems DA, Rath EA, Verrinder TR. Fatty acid synthesis in liver and adipose tissue of normal and genetically obese (ob/ob) mice during the 24-hour cycle. Biochem J. 1975;150:167-73.

51. Wiegman $\mathrm{CH}$, Bandsma RH, Ouwens $M$, van der Sluijs FH, Havinga R, Boer $T$, et al. Hepatic VLDL production in ob/ob mice is not stimulated by massive de novo lipogenesis but is less sensitive to the suppressive effects of insulin. Diabetes. 2003:52:1081-9.

52. Kuriyama H, Liang G, Engelking L, Horton JD, Goldstein JL, Brown MS. Compensatory increase in fatty acid synthesis in adipose tissue of mice with conditional deficiency of SCAP in liver. Cell Metab. 2005;1:41-51.

53. Cao H, Gerhold K, Mayers JR, Wiest MM, Watkins SM, Hotamisligil GS. Identification of a lipokine, a lipid hormone linking adipose tissue to systemic metabolism. Cell. 2008;134:933-44.

54. Weinstock PH, Levak-Frank S, Hudgins LC, Radner H, Friedman JM, Zechner $\mathrm{R}$, et al. Lipoprotein lipase controls fatty acid entry into adipose tissue, but fat mass is preserved by endogenous synthesis in mice deficient in adipose tissue lipoprotein lipase. Proc Natl Acad Sci U S A. 1997:94:10261-6.

55. Curat CA, Miranville A, Sengenes C, Diehl M, Tonus C, Busse R, et al. From blood monocytes to adipose tissue-resident macrophages: induction of diapedesis by human mature adipocytes. Diabetes. 2004;53:1285-92.

56. Bluher $M$. The distinction of metabolically 'healthy' from 'unhealthy' obese individuals. Curr Opin Lipidol. 2010;21:38-43.

57. Sorisky A, Molgat AS, Gagnon A. Macrophage-induced adipose tissue dysfunction and the preadipocyte: should I stay (and differentiate) or should I go? Adv Nutr. 2013;4:67-75.

58. Whitehead JP. Diabetes: New conductors for the peroxisome proliferatoractivated receptor gamma (PPARgamma) orchestra. Int J Biochem Cell Biol. 2011:43:1071-4

59. Janani C, Ranjitha Kumari BD. PPAR gamma gene - a review. Diabetes Metab Syndr. 2015:9:46-50
60. Kadowaki T, Hara K, Kubota N, Tobe K, Terauchi Y, Yamauchi T, et al. The role of PPARgamma in high-fat diet-induced obesity and insulin resistance. J Diabetes Complications. 2002;16:41-5.

61. Arimura N, Horiba T, Imagawa M, Shimizu M, Sato R. The peroxisome proliferator-activated receptor gamma regulates expression of the perilipin gene in adipocytes. J Biol Chem. 2004;279:10070-6.

62. Phan J, Peterfy M, Reue K. Lipin expression preceding peroxisome proliferatoractivated receptor-gamma is critical for adipogenesis in vivo and in vitro. J Biol Chem. 2004;279:29558-64.

63. Jones JR, Barrick C, Kim KA, Lindner J, Blondeau B, Fujimoto Y, et al. Deletion of PPARgamma in adipose tissues of mice protects against high fat diet-induced obesity and insulin resistance. Proc Natl Acad Sci U S A. 2005;102:6207-12.

64. Adida A, Spener F. Adipocyte-type fatty acid-binding protein as intercompartmental shuttle for peroxisome proliferator activated receptor gamma agonists in cultured cell. Biochim Biophys Acta. 2006;1761:172-81.

65. Lefterova MI, Zhang Y, Steger DJ, Schupp M, Schug J, Cristancho A, et al. PPARgamma and C/EBP factors orchestrate adipocyte biology via adjacent binding on a genome-wide scale. Genes Dev. 2008;22:2941-52.

66. Cai Y, Ying F, Song E, Wang Y, Xu A, Vanhoutte PM, et al. Mice lacking prostaglandin E receptor subtype 4 manifest disrupted lipid metabolism attributable to impaired triglyceride clearance. FASEB J. 2015:29(12):4924-36.

67. Huh JY, Kim JI, Park YJ, Hwang IJ, Lee YS, Sohn JH, et al. A novel function of adipocytes in lipid antigen presentation to iNKT cells. Mol Cell Biol. 2013;33:328-39.

68. Huh JY, Park YJ, Ham M, Kim JB. Crosstalk between adipocytes and immune cells in adipose tissue inflammation and metabolic dysregulation in obesity. Mol Cells. 2014;37:365-71.

69. Kotas ME, Lee HY, Gillum MP, Annicelli C, Guigni BA, Shulman Gl, et al. Impact of CD1d deficiency on metabolism. PLoS One. 2011;6:e25478.

70. Tajiri K, Shimizu Y. Role of NKT Cells in the Pathogenesis of NAFLD. Int J Hepatol. 2012;2012:850836.

71. Martin-Murphy BV, You Q, Wang H, De La Houssaye BA, Reilly TP, Friedman JE, et al. Mice lacking natural killer T cells are more susceptible to metabolic alterations following high fat diet feeding. PLoS One. 2014:9:e80949.

\section{Submit your next manuscript to BioMed Central and we will help you at every step:}

- We accept pre-submission inquiries

- Our selector tool helps you to find the most relevant journal

- We provide round the clock customer support

- Convenient online submission

- Thorough peer review

- Inclusion in PubMed and all major indexing services

- Maximum visibility for your research

Submit your manuscript at www.biomedcentral.com/submit 